\title{
Effect of Lactic Acid Bacteria on Mucosal Immune Cells against E. coli Infection in Poultry Birds
}

Siddique $\mathbf{A}^{1 *}$, Rahman $\mathbf{S}^{1}$, Ain $\mathbf{N}^{1}$ and Ullah khan $\mathbf{A}^{\mathbf{2}}$

${ }^{1}$ Department of Microbiology, University of Agriculture, Faisalabad, Pakistan

${ }^{2}$ Department of Anatomy, University of Agriculture, Faisalabad, Pakistan

\begin{abstract}
Poultry is a well-developed sector of agriculture industry in Pakistan. In poultry industry extensive antibiotics are used to control these pathogens for the improvement of meat and egg production. Present study was conducted to evaluate the impact of lactic acid producing bacteria on the immune status against $E$. coli infection in poultry birds. Lactobacillus spp. was isolated from conventional yoghurt sample. Lactobacillus spp. was isolated from yoghurt. In vivo analysis of Lactobacillus spp. against pathogenic $E$. coli was performed in poultry model. Three concentrations were maintaining 104, 105, $106 \mathrm{cfu} / \mathrm{ml}$ on the basis of McFarland standard were given to three groups. In vitro Macrophages migration inhibition factor assay was performed to check the cell mediated immune response in poultry birds against $E$. coli infection. The results showed that group administered with high Lactobacillus spp. Concentration showed highest \% inhibition of macrophages.
\end{abstract}

Keywords: Poultry; Lactic acid bacteria; E. coli; Macrophages; Migration inhibition factor; Mucosal immunology

\section{Introduction}

Poultry industry is a well-developed sector after textile in Pakistan. Poultry industry plays a major role in the GDP of Pakistan (GOP, 2013). Due to irrational use of antibiotics throughout poultry farming; and particularly against enteric pathogens are responsible for the emergence of resistance. Probiotics, are useful microbes, can be used as an alternate source of supplement food to reduce the involvement of pathogen [1,2]. Probiotics are safe to use and produce more health impacts on birds. Probiotics helps to increase mucosal immunity especially gastrointestinal immune system by direct acting on mucosa associated lymphoid tissue and gut associated lymphoid tissue. Many food borne pathogens play role in causing different digestive problems in poultry and influence the production of eggs and meat. In poultry industry extensive antibiotics are used to control these pathogens for the improvement of meat and egg production. The extensive use of antimicrobial drugs resulted in different problems such as development of drug residues in the poultry products and disturbance of normal microflora in the gut of bird [3-5].

E. coli is one of the important pathogen in livestock which affect its production. Due to extensive usage of antibiotics in the poultry results in the multidrug resistance against $E$. coli. As it is public health issues for the appearance of development of antibiotic resistance among zoonotic pathogens, is also challenging the poultry industry to find out the other means of pathogen control [6-10]. Probiotics can be defined as live microorganisms which contribute in the health of host by improving their intestinal microbial balance [11-13]. Different types of microorganisms like Lactobacillus and Lactcoccus are used as probiotic and they have a good effect on poultry health [14-16]. The mechanism for the control of pathogen by probiotics involves competition for nutrients, competition for binding sites on intestinal epithelium and production of mucosal immunity. Lactic acid bacteria (LAB) is an important probiotic which play a major role in increasing immunity, maintenance of Gut microbial balance and it also protect against pathogens in GIT. Association between probiotics and antigen detecting cells plays an important role in the production of mucosal homeostasis and the development of mucosal immunity [5].
Lactobacillus is a Gram+ve, non-spore forming, aero tolerant highly fermantive bacteria. Lactobacillus act as generally recognized as safe (GRAS) substances. It can be used as a safe drug in veterinary as well as medical application. Lactobacilli are commonly present in raw milk and different dairy products like yoghurts and chees. Lactobacilli have an inhibitory activity against common pathogens because they produce antimicrobial substances like bacteriocins and increased the mucosal immunity of the host [6].

Mucosal immunity is a localized and specific immune system which protects the inner surface of host body. It includes the mucosal surfaces of oral, gastrointestinal tract, respiratory tract and urogenital tract. The mucosal immunity has three important functions [7]. It protects the surface against colonization and invasion of dangerous pathogens in the host. It helps to prevent up take of ungraded antigens in which foreign proteins involved. It also helps by preventing the production of harmful immune responses to these antigens. Mucosal immunity of different organs has similar properties but GI mucosal immune system is better as compared to other organs. The GI mucosal immune system is composed of three major components epithelial layer, lamina propria and mucosal-associated lymphoid tissue [8]. This immune system is a highly specialized innate immune system which protects the mucous membranes from the pathogens. There are many pathogens present on the intestinal surface of chicken in which E. coli, salmonella spp. etc are present. Probiotics are important for the early production of intestinal immune system. The avian mucosal immune system has an effective antigen specific IgA antibody which resists enteric pathogens [9].

*Corresponding author: Siddique A, Department of Microbiology, University of Agriculture, Faisalabad, Pakistan, Tel: +923464942493; E-mail: Abubakars974@gmail.com

Received June 07, 2017; Accepted December 12, 2017; Published December 18, 2017

Citation: Siddique A, Rahman S, Ain N, Ullah khan A (2017) Effect of Lactic Acid Bacteria on Mucosal Immune Cells against $E$. coli Infection in Poultry Birds. Single Cell Biol 6: 168. doi:10.4172/2168-9431.1000168

Copyright: (c) 2017 Siddique A, et al. This is an open-access article distributed under the terms of the Creative Commons Attribution License, which permits unrestricted use, distribution, and reproduction in any medium, provided the original author and source are credited. 


\section{Materials and Methods}

\section{Sample collection}

Total 20 yoghurt samples (200gm each sample) were obtained from local shops in Faisalabad in sterilized polythene bags. Samples of yogurt were brought immediately to the laboratory, mixed by adding $100 \mathrm{ml}$ of phosphate buffer saline (PBS) in sterilized form [10].

\section{Isolation and identification}

Samples (200 g each sample) were obtained in sterilized polythene bags. For lactic acid bacteria isolation MRS agar media and MRS broth were used. MRS agar plates were inoculated and incubated anaerobically at $37^{\circ} \mathrm{C}$ in anaerobic jar for $48 \mathrm{hrs}$ [11]. For the growth of Lactobacilli, they were presumptively identified following the methods described in Bergey's Manual of Systematic Bacteriology. Macroscopic appearance of all the colonies, which were obtained after 48 hours of incubation on MRS agar plates, was examined for cultural and morphological characteristics. Size, shape, colour and texture of the colonies were noted. Bacterial isolates were tested for catalase production by catalase test [12]. Cell morphology was examined after Gram staining and spore staining. Gram+ve, non-spore forming rods showing catalase negative test were further identified by sugar fermentation tests [13].

\section{In vivo evaluation of Lactobacillus species against E. coli}

One day old broiler chicks (60) were placed in animal house of Institute of Microbiology for 15 days. They were divided into four groups on the basis of different concentration. Three concentrations were maintaining 104, 105 and $106 \mathrm{cfu} / \mathrm{ml}$ on the basis of McFarland standard, were given to three groups. One group is control. Lactobacillus spp was administered in water. A challenge infection of avian pathogenic E. coli obtained from institute of microbiology was given to birds on day 7. Macrophages and plasma cells were collected before and after challenge infection [14].

\section{Collection of macrophages}

Isolation of macrophages was done by the method which is filling a $10 \mathrm{ml}$ syringe with $3 \%$ Brewer thioglycollate medium. Attach 25-G needle and inject $2 \mathrm{ml}$ of the solution per mouse into the peritoneal cavity. Soak the abdomen of each bird with $70 \%$ alcohol and then make a small incision along the midline with sterile scissors. Retract the abdominal skin manually to expose the intact peritoneal wall. Fill a $5 \mathrm{ml}$ syringe with cold harvest medium Dulbecco phosphate buffer saline with the beveled end of a $20-G$ needle facing inward, insert needle through peritoneal wall along the birds left side (spleen side) and inject $5 \mathrm{ml}$ of the cold harvest medium into each bird. Using the same syringe and needle, aspirate fluid from peritoneum [15]. Move needle away from the viscera to cause tenting of the peritoneal wall, and withdraw peritoneal fluid slowly. Remove needle from syringe and dispense peritoneal fluid into a $50 \mathrm{ml}$ conical Polypropylene centrifuge tube on ice. Centrifuge the peritoneal exudate cells (PEC) in a refrigerated centrifuge $10 \mathrm{~min}$ at $1500 \mathrm{RPM} 4^{\circ} \mathrm{C}$. Discard supernatant and suspend cell pellet in cold Dulbecco phosphate buffer saline. Count cells a haemocytometer; the cell concentration is maintained $1 \times 10^{4}$ cells/mL (refrigeration temp).

\section{Macrophages migration inhibition factor assay}

Macrophage migration inhibition test will be performed as an in vitro correlation of cellular immunity against E. coli. $3 \%$ of Agarose gel was prepared in distill water liquefy the gel at boiling temperature. A droplet of Agarose gel was placed at the center of each well of 24 well microliter plates. Minimal Essential medium RPMI-1640 was pour in 24 wells plate $(200 \mu \mathrm{l})$ and mixed with (two fold) diluted test plasma that is treated with E. coli. Glass capillary tube of $5 \mathrm{~cm}$ long and $2 \mathrm{~mm}$ internal diameter which was $2 / 3$ rd filled with macrophages collected from infected and non-infected birds were adjusted into the each wells. Incubation is at $37^{\circ} \mathrm{C}$ for 24 hours and measuring migration distance from the tip of capillary tube [16]

Percent inhibition is calculated by the formulae:

$\%$ inhibition $=1$ - (Area of migration in the presence of antigen/Area of antigen in the absence of antigen) $\times 100$

\section{Statistical analysis}

Data was analyzed by applying Standard Error (Mean \pm SE) and analysis of variance (ANOVA) under completely randomized design Table 1 and Graph 1.

\section{Results}

Total 20 samples were collected from local market of Faisalabad city and screened for the presence of Gram+ve and catalase negative lactic acid bacteria. All the samples were processed and screened fifteen samples showed the presence of lactobacillus spp. It shows that lactobacillus spp. has dominance in fermented milk products. All the isolates were identified as lactic acid bacteria on the basis of their gram reaction, catalase activity, morphological and cultural characteristics. Lactobacillus spp. are gram+ve, rod shaped and appeared purple in color under light microscope. Colonies on MRS medium appeared circular, smooth and white to creamy in color. Pure isolates were maintained in MRS broth at $-20^{\circ} \mathrm{C}$ with $10 \%(\mathrm{v} / \mathrm{v})$ glycerol. Macrophages were isolated from the peritoneal cavity of poultry birds by the procedure as described above. Macrophages collected and pelleted by centrifugation then suspend in Dulbecco's phosphate buffer saline and maintained $1 \times$ $10^{4}$ cells/ml by counting in haemocytometer. After centrifugation and lymphocytes treated with $E$. coli. This test shows in vitro correlation of

\begin{tabular}{|c|c|c|c|c|c|}
\hline $\begin{array}{c}\text { No. of Plasma } \\
\text { Dilutions }\end{array}$ & Group A & Group B & Group C & Group D & Mean \\
\hline 1 & 32.1 & 47.1 & 56.5 & 66.6 & $50.58 \pm 7.33 \mathrm{~A}$ \\
\hline 2 & 32.0 & 45.0 & 52.8 & 64.8 & $48.65 \pm 6.88 \mathrm{~B}$ \\
\hline 3 & 31.2 & 44.8 & 51.2 & 64.0 & $47.80 \pm 6.82 \mathrm{BC}$ \\
\hline 4 & 31.0 & 44.5 & 50.3 & 62.6 & $47.10 \pm 6.56 \mathrm{BC}$ \\
\hline 5 & 31.0 & 44.5 & 50.0 & 61.7 & $46.80 \pm 6.37 \mathrm{C}$ \\
\hline 6 & 25.0 & 43.0 & 47.6 & 60.7 & $44.08 \pm 7.38 \mathrm{D}$ \\
\hline Mean & $30.38 \pm$ & $44.82 \pm$ & $51.40 \pm$ & $63.40 \pm$ & - \\
\hline
\end{tabular}

Means sharing similar letters in a row or in a column are statistically non-significant $(P>0.05)$.

Table 1: Means of $\%$ inhibition.

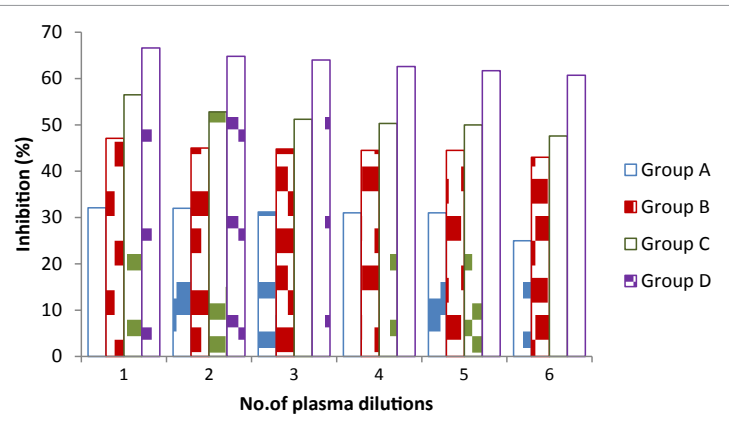

Graph 1: Percent inhibition of macrophages by each group. 
Citation: Siddique A, Rahman S, Ain N, Ullah khan A (2017) Effect of Lactic Acid Bacteria on Mucosal Immune Cells against E. coli Infection in Poultry Birds. Single Cell Biol 6: 168. doi:10.4172/2168-9431.1000168

Page 3 of 3

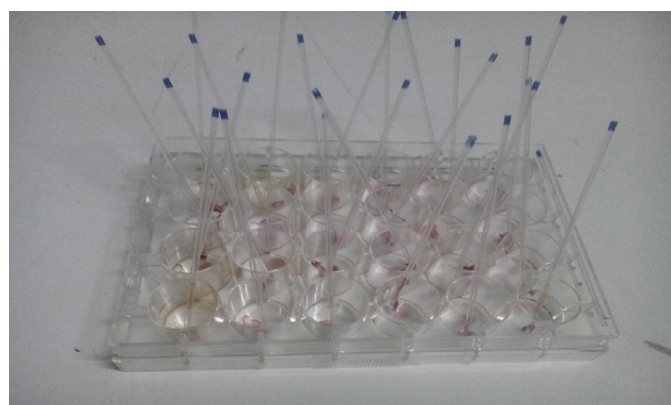

Figure 1: In vitro macrophage migration inhibition factor assay.

cellular immunity with specific E. coli infection in poultry birds. Zones of inhibition are formed at different concentration of different groups which were observed and $\%$ inhibition was calculated by measuring distance from the tip of capillary tube, Macrophage migration index of different groups.

\section{Discussion}

The purpose of this study was to check the effect of lactic acid bacteria on mucosal front against $E$. coli in poultry birds. Lactic acid bacteria are Generally Recognized as Safe and are strong candidate to replace antibiotic. They can be used as natural competitive micro flora and have antimicrobial activity. Although the lactic acid bacteria are normal habitant of GI tract and oral cavity so they are strong candidate to replace antibiotic and best alternative for antibiotic therapies [16]. Multidrug resistance and irrational use of antibiotics is an emerging problem to control pathogens in both humans and animals. Effect of Lactobacillus showed better immune response against $E$. coli by producing beneficial impact on mucosal front by producing more active MIF response and produce maximum results against E. coli (Figure 1).

\section{Conclusion}

It is recommended that these locally isolated Lactobacilli may be used as probiotics after species/strain identification through molecular methods and extensive field trials. It is recommended on the basis of our results that Lactobacillus spp. can be used as antimicrobial agent after purification and characterization. It is also recommended that in future studies, other bacterial spp. Of lactobacillus should be extracted and evaluated their potential to inhibit the growth of pathogens as antimicrobial agents at commercial level.

\section{References}

1. Chowdhury A, Hossain MN, Mostazir NJ, Fakruddin M, Billah MM, et al (2012) Screening of Lactobacillus spp. from buffalo yoghurt for probiotic and antibacterial activity. J Bacteriol Parasitol 3: 156.

2. Cintas LM, Herranz C, Hernández PE, Casaus MP, Nes LF (2001) Review bacteriocins of lactic acid bacteria. Food Sci Tech Int 7: 281-305.

3. Deng J, Li Y, Zhang J, Yang Q (2013) Co-administration of Bacillus subtilis rjgp16 and Lactobacillus salivarius b1 strongly enhances the intestinal mucosal immunity of piglets. Res Vet Sci 94: 62-68.

4. Di Cerbo A, Palmieri B (2013) Lactobacillus paracasei subsp. paracasei f19; a farmacogenomic and clinical update. Nutr Hosp 28: 1842-1850.

5. Government of Pakistan (2013) Pakistan Economic survey. Ministry of Finance Islamabad.

6. Harrigan WF, McCance ME (1976) Laboratory methods in food and dairy. Microbiology. Academic press London, UK. pp: 19-20.

7. Holmgren J, Czerkinsky C (2005) Mucosal immunity and vaccines. Nature Med 11: 45-53.

8. Kandler O, Weiss N (1986) Regular, non-sporing gram-positive rods. In Bergey's Manual of Systematic Bacteriology. Sneath PHA, Mair NS, Sharpe ME and Holt JG (eds), Williams and Williams, Baltimore. pp: 1208-1234.

9. Sneath PHA, Mair ANS, Sharpe ME, Holt JG (1986) Genus Cellulomonas Bergey's manual of systematic bacteriology. Williams and Wilkins, Baltimore 2: $1325-1329$.

10. Kral M, Angelovi M, Mrazova L (2012) Application of probiotics in poultry production. Animal Sci and Biotech 45: 55-57.

11. Millman JM, Waits K, Grande H, Marks AR, Marks JC, et al. (2013) Prevalence of antibiotic-resistant $\mathrm{E}$. coli in retail chicken: comparing conventional, organic, kosher, and raised without antibiotics. Version 2. F1000Res 2: 155.

12. Muir WI, Bryden WL, Husband AJ (2000) Immunity, vaccination and the avian intestinal tract. Develop Comp Immunol. 24: 325-342.

13. Tellez G, Pixley C, Wolfenden R (2012) Probiotics/direct fed microbial for Salmonella control in poultry. Food Research Intern 45: 628-633.

14. Tsai YT, Cheng PC, Liao JW, Pan TM (2010) Effect of the administration of Lactobacillus paracasei subsp. paracasei ntu 101 on peyer's patch-mediated mucosal immunity. Internat Immunopharma 10: 791-798.

15. West NP, Pyne DB, Peake JM, Cripps AW (2009) Probiotics, immunity and exercise: A review. Exerc Immunol Rev 15: 107-126.

16. Wu RQ, Zhang DF, Tu E, Chen QM, Chen W (2014) The mucosal immune system in the oral cavity-an orchestra of $\mathrm{t}$ cell diversity. Intern J Oral Sci 6 : 125-132. 